Chirurgia (2020) 115: 208-212

No. 2, March - April

Copyright@ Celsius

http://dx.doi.org/10.21614/chirurgia.115.2.208

\title{
Laparoscopic Cholecystectomy in the Cirrhotic: Review of Literature on Indications and Technique
}

\author{
Elisa Cassinotti', Ludovica Baldari', Luigi Boni', Selman Uranues², Abe Fingerhut ${ }^{2,3}$ \\ 'Department of General and Emergency Surgery IRCCS-Ca'Granda Policlinico Hospital, University of Milan, Italy \\ ${ }^{2}$ Section for Surgical Research, Department of Surgery, Medical University of Graz, Graz, Austria \\ ${ }^{3}$ Department of General Surgery, Ruijin Hospital, Shanghai Jiao Tong University School of Medicine Shanghai Minimally Invasive \\ Surgery Center, Shanghai, P. R. China
}

Corresponding author: Elisa Cassinotti, MD, PhD

Department of General and Emergency Surgery

IRCCS-Ca'Granda Policlinico Hospital University of Milan, Italy

E-mail: cassinotti.elisa@gmail.com

\section{Rezumat \\ Colecistectomia laparoscopică în ciroză: revizuirea literaturii privind indicațiile și tehnica}

Litiaza biliară este de două ori mai frecventă la pacienții care suferă de ciroză hepatică comparativ cu populația totală şi la acei pacienți, colecistita acută apare semnificativ mai des. Scopul nostru a fost să trecem în revistă literatura de specialitate şi să prezentăm o privire de ansamblu a indicațiilor, contraindicațiilor şi alternativelor în ciroza cu litiază biliară. Am efectuat o revizuire sistematică a literaturii folosind cuvintele cheie „ciroză”, „colecistectomie”, „laparoscopie” şi „indicatiii”. Articolele selectate au fost revizuite pentru informații specifice indicațiilor, contraindicațiilor şi alternativelor la colecistectomia laparoscopică în ciroze. Rezultatele au arătat că colecistectomia laparoscopică poate oferi mai multe avantaje pentru populația cirotică, cu toate acestea colecistectomia poate fi provocatoare: indicatiile specifice şi alternativele chirurgicale trebuie discutate de la caz la caz. Colecistectomia laparoscopică poate fi efectuată în condiții de siguranță la pacienții selectați cu ciroză; sunt necesare precauții speciale în ceea ce priveşte presiunea pneumoperitoneului, plasarea trocarului şi siguranța sporită cu colangiografie fluorescentă verde-indocianină (ICG). Cu toate acestea, la pacienții cirotici cu risc ridicat şi/sau în căile biliare comune litiaza endoscopică şi non-chirurgicală sunt tratamentele preferate.

Cuvinte cheie: ciroză, colecistectomie, laparoscopie 


\section{Abstract}

Cholelithiasis is twice more common in patients suffering from liver cirrhosis compared to overall population and in those patients, acute cholecystitis occurs significantly more often. Our goal was to review the literature and to overview the indications, contra-indications, and alternatives in the cirrhotic with biliary stones. We conducted a systematic review of the literature using the key words "Cirrhosis", "cholecystectomy", "laparoscopy", and "indications". Selected articles were reviewed for information specific to indications, contra-indications, and alternatives to laparoscopic cholecystectomy in cirrhotics. Results showed that laparoscopic cholecystectomy might offer several advantages in cirrhotic population, however cholecystectomy can be challenging: specific indications and alternatives to surgery must be discussed case by case. Laparoscopic cholecystectomy can be performed safely in selected patients with cirrhosis; special precautions are warranted regarding pneumoperitoneum pressure, trocar placement and increased safety with Indocyanine-green (ICG) fluorescence cholangiography. Nevertheless, in high-risk cirrhotic patients (Child C) and/or in common bile duct lithiasis endoscopic and non-surgical conservative treatments are preferable.

Key words: cirrhosis, cholecystectomy, laparoscopy

\section{Introduction}

Cholelithiasis is found in about one third of patients with liver cirrhosis (1), about twice as much as in the overall population (2). Predisposing factors found in the literature include gallbladder dysmotility (reduced motility and decreased emptying) in the fibrous transformed liver, reduction in bile acidity, increased unconjugated bilirubin secretion, increased levels of estrogen, and increased intravascular hemolysis due to hypersplenism $(1,3-7)$. Symptomatic biliary stones in patients with liver cirrhosis are associated with higher morbidity (8) and mortality rates than those in patients with a non-cirrhotic liver (9) and in particular when patients with advanced cirrhosis undergo surgery (10). Acute cholecystitis occurs more often in the cirrhotic: $47 \%$ versus $14.7 \%$ in patients with or without cirrhosis, respectively $(\mathrm{p}<0.001)$. Our goal was to review the literature and to overview the indications, contra-indications, and alternatives in the cirrhotic with biliary stones.

\section{Methods}

We conducted a systematic review of the literature using the key words "Cirrhosis", "cholecystectomy", "laparoscopy", and "indica- tions". Of the 136,000 possible references, we further screened for articles in English and and published in indexed journals. After eliminating redundant publications and (second hand) citations, we analyzed 32 articles (1,3,4,7-35). Selected articles were reviewed for information specific to laparoscopic cholecystectomy in cirrhotic, indications and contraindications and possible alternatives.

\section{Results}

The indications and contra-indications for laparoscopic cholecystectomy in the cirrhotic patient and possible alternatives are problems that all surgeons today may encounter. Specific indications and contra-indications must be known before work-up.

The advantages of laparoscopic cholecystectomy include: minimal tissue trauma and reduced surgical stress, reduced postoperative immune suppression, less exposure of viscera, less fluid and protein loss, less " third sector" sequestration, less respiratory compromise, less need for organ luxation, and less interruption of the abdominal wall collateral circulation.

However, cholecystectomy in the cirrhotic can be challenging in many aspects leading to several specific recommendations for laparos- 
copic cholecystectomy in this high-risk group of patients.

Alternatives to surgery must be discussed case by case.

\section{Discussion}

Liver cirrhosis increases the difficulty of cholecystectomy, particularly in those patients with severe liver fibrosis (difficulty and fragility in retraction) and portal hypertension (increased bleeding). Because of these increased risks, open cholecystectomy (OC) was originally preferred over laparoscopic cholecystectomy (LC) when surgery became necessary $(4,11,12)$.

Several small series, randomized or not, have surfaced in the literature as early as 1993 (13), stating that laparoscopic cholecystectomy could be performed safely in selected patients with cirrhosis $(9,11,14)$, and currently, laparoscopic cholecystectomy has become the preferred approach in specific indications $(8,11,15)$.

However, the laparoscopic approach has specific shortcomings in the cirrhotic, and special precautions are warranted.

As the hepatic portal inflow in the cirrhotic is decreased, the hepatic buffer response is impaired (increased hepatic artery inflow to compensate the decreased portal inflow). Because of this, Cobb et al. recommend to keep the intra-abdominal pressure as low as possible, and exsufflate cautiously, intermittently (11). N'Guyen et al. made the following recommendations (36) (Table 1).
Several operative details have their importance.

1. Operative setup: while it is recognized that trocars interrupt the collateral circulation less than a midline, the periumbilical area should be avoided (37);

2. Once the first trocar is inserted, transillumination of abdominal wall allows to avoid the collaterals (37);

3. Placement of subxiphoid port to the right of the midline avoids injury to the falciform ligament and the (potentially repermeabilized) umbilical vein;

4. If the left lobe encroaches on the operative field, the surgeon should raise patient's right shoulder and/or use a long port or converter inserted into the epigastric port, or if not sufficient, insert an extra port to retract the left lobe;

5. Intra-operatively, it is essential to avoid excessive traction on the gallbladder to avoid avulsion from the liver bed (37);

6. Last, as for other operations in the cirrhotic, especially with ascites, intraperitoneal drains should be avoided (38).

When the patient is Child C, or MELD > 13, laparoscopic surgery is not recommended and several alternatives have been suggested such as partial cholecystectomy (17) or endoscopic drainage of the gallbladder $(21,28)$, the latter especially in patients who may someday be candidates for liver transplantation. In high risk patients with acute cholecystitis, percutaneous cholecystostomy $(26,34,39)$ has been favored. However, in these patients, the risk of

Table 1.

\begin{tabular}{l} 
Pre-operative \\
\hline a) Medically optimize the patient: control ascites, correct coagulopathy [fresh frozen plasma (when INR $>1.5)$ and platelets $\left.\left(<50 / \mathrm{mm}^{3}\right)\right]$ \\
\hline b) Cirrhotic patients with hemoglobin $<10 \mathrm{~g} / \mathrm{dL}$ should receive corrective blood transfusions before abdominal surgery \\
\hline c) Obtain pre-operative imaging to help identify abdominal wall varices or a recanalized umbilical vein and to rule-out hepatoma \\
\hline d) Consider cholecystostomy tube in patients with Child class C (MELD $>13)(4)$ \\
Intra-operative \\
\hline a) Use the open Hasson approach via an infra-umbilical incision to avoid periumbilical wall varices \\
\hline b) Transilluminate with the laparoscope to identify vascular collaterals or measure placement based on preoperative imaging \\
\hline c) If unsuspected cirrhosis is identified during a planned routine laparoscopic cholecystectomy, depending on the experience of the surgeon \\
and the facilities; consider closing the fascia and skin and transferring the patient to a tertiary medical center with critical care, hepatology, \\
and hepatobiliary and transplant surgery support
\end{tabular}


hemorrhage and/or sepsis in portal hypertension and/or ascites is high. This has led to a debate as to whether the transhepatic or transperitoneal route should be used.

The transhepatic route preferred by many because it minimizes the risk of intraperitoneal bile leak, inadvertent injury to the hepatic flexure of the colon (27) [colon positioned between skin and gallbladder fundus in $13 \%$ of patients (33)].

In order to facilitate visualization of biliary structures and to reduce time to get the critical view of safety, indocyanine green fluorescent cholangiography has been introduced in clinical practice as a promising tool. Recently, a randomized control trial (40) demonstrated that this technique is statistically significantly superior to standard technique visualizing extrahepatic biliary structures during laparoscopic cholecystectomy. However, a pre-existing liver disease was an exclusion criterion from this study. According to literature, no studies stating the feasibility of indocyanine green (ICG) fluorescent cholangiography in cirrhotic patients are available. ICG can be already used to assess portal hypertension and esophageal varices in patient with compensated liver cirrhosis (Child A) (41) and to estimate short term survival in decompensated cirrhosis thorough the ICG elimination test $(42,43)$. One of the clinical applications of ICG (44) in fluorescence guided hepatobiliary surgery is liver mapping. Aoki et al (45) reported no significant differences in the mapping of the liver segments between non-cirrhotic and cirrhotic patients using ICG fluorescence. Taking into account these clinical applications and results, feasibility studies are necessary to determine the use of ICG fluorescence cholangiography and or near-infrared cholecystocholangiography with direct intra-gallbladder indocyanine green injection (46).

In patients with CBD stones, the risk of morbidity and mortality is high, ranging from 2 to $30-50 \%(16,18,23,24,30)$. In this setting, endoscopic management is preferred $(18,19$, 30) although mortality is still around 15\% $(18,31)$ (vs. overall complication rate of about
$10 \%$ and a mortality rate of $0.5 \%$ in noncirrhotics) (20,35). Endoscopic papillary balloon dilatation without sphincterotomy is associated with a lower risk of bleeding but is of limited efficacy in case of large stones (32). Endoscopic treatment with mechanical lithotripsy or sphincterotomy is recommended for larger stones (32).

\section{Conclusions}

Laparoscopic cholecystectomy could be performed safely in selected patients with cirrhosis. Special precautions are requested regarding pneumoperitoneum pressure, trocar placement and the use of ICG fluorescence intraoperative cholangiography to increase safety during bile ducts dissection.

Nevertheless in high-risk cirrothic patients (Child C, severe ascites) and/or in patients suffering from gallbladder and CBD stones, endoscopic and non-surgical conservative treatments are recommended.

\section{Conflict of Interests}

No conflicts of interes.

\section{References}

1. Acalovschi M. Gallstones in patients with liver cirrhosis: Incidence, etiology, clinical and therapeutical aspects. World J Gastroenterol 2014:20:7277-7285.

2. Bouchier I A D. Postmortem study of the frequency of gallstones in patients with cirrhosis of the liver. Gut. 1969;10:705-10.

3. Conte D, Fraquelli M, Mandelli C, Braga M, Casarin P, Bodini P et al. Probability of developing gallstones and related risk factors in 400 cirrhotics. Eur J Gastroenterol Hepatol. 1994;6:55-58.

4. Delis S, Bakoyiannis A, Madariaga J, Bramis J, Tassopoulos N, Dervenis C. Laparoscopic cholecystectomy in cirrhotic patients: the value of MELD score and Child-Pugh classification in predicting outcome. Surg Endosc. 2010;24:407-412.

5. Machado NO. Laparoscopic cholecystectomy in cirrhotics. JSLS. 2012:16:392-400.

6. Quillin RC, Burns JM, Pineda JA, Hanseman D, Rudich SM, Edwards MJ, Tevar AD. Laparoscopic cholecystectomy in the cirrhotic patient: predictors of outcome. Surgery. 2013;153:634-40.

7. Schwesinger WH, Kurtin WE, Levine BA, Page CP. Cirrhosis and alcoholism as pathogenetic factors in pigment gallstone formation. Ann Surg. 1985:201:319-322.

8. de Goede PJ, Klitsie SM, Hagen BJH, van Kempen S, Spronk HJ, Metselaar HJ, Lange JF, Kazemier G. Meta-analysis of laparoscopic versus open cholecystectomy for patients with liver cirrhosis and symptomatic cholecystolithiasis. Br J Surg. 2013;100:209-216.

9. Hamad MA, Thabet M, Badawy A, Mourad F, Abdel-Salam M, 
Abdel-Rahman Mel-T et al. Laparoscopic versus open cholecystectomy in patients with liver cirrhosis: a prospective, randomized study. J Laparoendosc Adv Surg Tech A. 2010;20:405-409.

10. Clark JR, Wills VL, Hunt DR. Cirrhosis and laparoscopic cholecystectomy. Surg Laparosc Endosc Percutan Tech. 2001;11:165-169.

11. Cobb WS, Heniford BT, Burns JM, Carbonell AM, Matthews BD Kercher KW. Cirrhosis is not a contraindication to laparoscopic surgery. Surg Endosc. 2005;19:418-423.

12. Cucinotta E, Lazzara S, Melita G. Laparoscopic cholecystectomy in cirrhotic patients. Surg Endosc. 2003;17:1958-1960.

13. Yerdel MA, Tsuge H, Mimura H, Sakagami K, Mori M, Orita K. Laparoscopic cholecystectomy in cirrhotic patients: expanding indications. Surg Laparosc Endosc. 1993;3:180-183.

14. Morino M, Cavuoti G, Miglietta C, Giraudo G, Simone P. Laparoscopic cholecystectomy in cirrhosis: contraindication or privileged indication? Surg Laparosc Endosc Percutan Tech. 2000; 10:360-363.

15. Puggioni A, Wong LL A Meta-analysis of laparoscopic cholecystectomy in patients with cirrhosis. J Am Coll Surg. 2003;197:921-926.

16. Bloch RS, Allaben RD, Walt AJ. Cholecystectomy in patients with cirrhosis. A surgical challenge. Arch Surg. 1985;120:669-672.

17. Elshaer M, Gravante,G, Thomas K, Sorge R, Al-Hamali S, Ebdewi H Subtotal Cholecystectomy for "Difficult Gallbladders" Systematic Review and Meta-analysis. JAMA Surg. 2015;150:159-168.

18. Elzouki AN, Nilsson S, Nilsson P, Verbaan $H$, Simanaitis $M$, Lindgren $\mathrm{S}$. The prevalence of gallstones in chronic liver disease is related to degree of liver dysfunction. Hepatogastroenterology. 1999:46:2946-2950

19. Fernandes NF, Schwesinger WH, Hilsenbeck SG, et al. Laparoscopic cholecystectomy and cirrhosis: a case-control study of outcomes. Liver Transpl. 2000;6:340-344.

20. Freeman ML, Nelson DB, Sherman S, Haber GB, Herman M, Dorsher P, Moore J, Fennerty MB, Yan MR, Shaw MJ, Lande JD, Heley AMP Complications of endoscopic biliary sphincterotomy N Eng J Med. 1996:335:909-18.

21. Gaglio PJ, Buniak B, Leevy CB Primary endoscopic retrograde cholecystoendoprosthesis: a nonsurgical modality for symptomatic cholelithiasis in cirrhotic patients. Gastrointest Endosc. 1996; 44:339-42.

22. Gulberg V, Haag K, Rossle M, Gerbes AL. Hepatic arterial buffer response in patients with advanced cirrhosis Hepatology. 2002:35: 630-4.

23. Isozaki H, Okajima K, Morita S, Ishbashi T, Tanimura M, Hara H, Takeda Y Surgery for cholelithiasis in cirrhotic patients. Surg Today. 1993:23:504-8.

24. Moreira VF, Arribas R, Sanroman AL, Merono E, Larena C, Garcia $M$, Torres G. Choledocholithiasis in cirrhotic patients: is endoscopic sphincterotomy the safest choice? Am J Gastroenterol 1991;86: 1006-10.

25. Natsui M, Narisawa R, Motoyama H, Hayashi S, Seki K, Wakabayashi $\mathrm{H}$, Itoh $\mathrm{S}$, Asakura $\mathrm{H}$ What is an appropriate indication for endoscopic papillary balloon dilation? Eur J Gastroenterol Hepatol. 2002;14:635-40.

26. Pavurala RB, Li DD, Porter K, Mansfield SA, Conwell DL, Krishna SG Percutaneous cholecystostomy-tube for high-risk patients with acute cholecystitis: current practice and implications for future research Surg Endosc 2019 doi: 10.1007/s00464-018-06634-5.

27. Pinheiro RH, Waisberg DR, Lai Q, Andraus W, Nacif LS, RochaSantos V, D'Albuquerque LAC Laparoscopic cholecystectomy and cirrhosis: patient selection and technical considerations Ann LAparsoc Endosc Surg. 2017;2:35-44.

28. Shrestha R, Grunkemeier DMS Endoscopic treatment of biliary tract disease prior to orthotopic liver transplantation Current
Treatment options in Gastroenterology. 2006;9,133-144.

29. Silva MA, Wong T. Gallstones in chronic liver disease. J Gastrointest Surg. 2005;9:739-746.

30. Sirinek KR, Burk RR, Brown, M, Levine BA Improving survival in patients with cirrhosis undergoing major abdominal operations .Arch Surg. 1987;122:271-3.

31. Sugiyama M, Atomi Y, Kuroda A, Muto T. Treatment of choledocholithiasis in patients with liver cirrhosis. Surgical treatment or endoscopic sphincterotomy? Ann Surg 1993;218:68-73.

32. Weinberg B, Shidy W, Lo S Endoscopic balloon sphincter dilation (sphincteroplasty) versus sphincterotomy for common bile duct stones. Cochrane Cochrane Systematic Review Version published: 18 October 2006. https://doi.org/10.1002/14651858.CD004890.pub2

33. Warren LP, Kadir S, Dunnick NR Percutaneous cholecystostomy: anatomic considerations. Radiology. 1988;168:615-6.

34. Winbladh A, Gullstrand P, Svanvik J, Sandström P Systematic review of cholecystostomy as a treatment option in acute cholecystitis. HPB. 2009;11:183-193.

35. Wojtun S, Gil J, Gietka W, Gil M. Endoscopic sphincterotomy for choledocholithiasis: A prospective single-center study on the short-term and long-term treatment results in 483 patients. Endoscopy. 1997;29:258-265.

36. Nguyen KT, Kitisin K, Steel J, Jeyabalan G, Aggarwal S, Geller DA, et al. Cirrhosis is not a contraindication to laparoscopic cholecystectomy: results and practical recommendations. HPB (Oxford). 2011;13:192-7.

37. Sleeman D, Namias N, Levi D, Ward FC, Vozenilek BSJ, Silva R, et al. Laparoscopic cholecystectomy in cirrhotic patients. J Am Coll Surg 1998; 187: 400-403

38. Liu CL, Fan ST, Lo CM, Wong Y, Ng IOL, Lam CM, et al. Abdominal Drainage After Hepatic Resection Is Contraindicated in Patients With Chronic Liver Diseases. Ann Surg. 2004;239:194-201.

39. Byrne MF, Suhocki P, Mitchell RM, Pappas TN, Stiffer HL, Jowell PS, et al. Percutaneous cholecystectomy in patients with acute cholecystitis: experience of 45 patients at a US referral center. J Am Coll Surg. 2003;197:206-11.

40. Dip F, LoMenzo E, Sarotto L, Phillips E, Todeschini H, Nahmod M, et al. Randomized Trial of Near-infrared Incisionless Fluorescent Cholangiography. Ann Surg. 2019 Jan 9. doi: 10.1097/SLA. 0000000000003178. (Epub ahead of print)

41. Lisotti A, Azzaroli F, Buonfiglioli F, Montagnani M, Cecinato P, Turco $\mathrm{L}$, et al. Indocyanine green retention test as a noninvasive marker of portal hypertension and esophageal varices in compensated liver cirrhosis. Hepatology. 2014;59:643-50.

42. Stauber RE, Wagner D, Stadlbauer V, Palma S, Gurakugi G, Kniepeiss D, et al. Evaluation of indocyanine green clearance and model for end-stage liver disease for estimation of short-term prognosis in decompensated cirrhosis. Liver Int. 2009;29:1516-20.

43. Merkel C, Bolognesi M, Finucci GF, Angeli P, Caregaro L, Rondana $M$, et al. Indocyanine green intrinsic hepatic clearance as a prognostic index of survival in patients with cirrhosis. J Hepatol. 1989:9:16-22.

44. Majlesaraa A, Golriza M, Hafezia M, Saffari A, Stenaub E, MaierHeinb L, et al. Indocyanine green fluorescence imaging in hepatobiliary surgery. Photodiagnosis Photodyn Ther. 2017;17:208-215.

45. Aoki T, Murakami M, Yasuda D, Shimizu Y, Kusano T, Matsuda K, et al. Intraoperative fluorescent imaging using indocyanine green for liver mapping and cholangiography, J. Hepatobiliary Pancreat Sci. 2010:590-594.

46. Liu YY, Liao CH, Diana M, Wang SY, Kong SH, Yeh CN, et al. Nearinfrared cholecystocholangiography with direct intragallbladder indocyanine green injection: preliminary clinical results. Surg Endosc. 2018;32:1506-1514. 